\title{
Subsurface Temperature Prediction from Multilayer Solution of Heat Flow Equation: A Case Study of Anambra Sedimentary Basin, Nigeria
}

\author{
Emujakporue, Godwin Omokenu ${ }^{1}$ and Nwosu, Leonard Ifeanyi. \\ Department of Physics, University of Port Harcourt, Rivers State, Nigeria
}

\begin{abstract}
The thermal structure of parts of Anambra sedimentary basin has been determined by applying a simple analytical technique of thermal resistance solution to heat flow equation. In this research, multilayer solution was derived from the heat flow equation with the assumption that the average bulk thermal conductivity of a layer sequence is equal to the harmonic average of the corresponding single layer bulk thermal conductivity. The subsurface temperature was obtained for seven formations in the basin. The computed geotherms for the sediment increase with depth. The geotherms show zones of steep and low increases in temperature with depth. These zones of steep and low gradient correspond to low and high values of thermal conductivities. The accuracy of the temperature model depends on the quality of thermal conductivities, assumed basal heat flow and thickness of layers used as input data in the model. It was observed that the Imo and Ajali Formation have higher thermal conductivities while the Ogwashi-Asaba has the least value. The results of the model temperatures were compared with measured bottom hole temperatures from six deep wells and a good fit was observed between the two datasets. The results of the modelling were able to effectively characterize the thermal structure in the study basin.

Keywords: Thermal modelling; Multilayer; bottom hole temperature; thermal conductivity.
\end{abstract}

\section{Introduction}

The spatial variation of surface heat flow values depends on subsurface temperature distribution and the pattern of which is directly controlled by the variation of rock thermal conductivity values. Knowledge of subsurface temperature distribution can help in the interpretation of the thermal structure of a region as well as mantle convection, plate tectonics, mountain building and thermal maturation of hydrocarbon in the subsurface (Beardsmore and Cull,. 2001: Putra et al., 2014).

The thermal structure of the earth depends on its thermal conductivity, radiogenic heat sources, basal heat flow and surface temperature. Many researchers have carried out work on the thermal evolution of the earth and the terrestrial heat flow for purpose of exploration and exploitation of hydrocarbons or geothermal energy (Whiteford and Graham,1994: Chapman and Rybach,1985: Chapman et al,. 1984). Most of these sedimentary basins heat flow and temperatures modelling have been computed from measured borehole temperatures. Numerical analysis has also been used to quantify the thermal state of some basins (Stuwe, 2008: Goff and Janik, 2000). Analytical steady state model can also be used to approximate the geothermal properties of a basin in areas with limited data or lack of borehole temperatures.

Geothermal heat flow is a natural mechanism by which heat is transferred from the hotter, inner part to the cooler surface of the Earth (Goff and Janik, 2000). Heat transport can be by radiation, conduction and convection in sediments (Cengel and Ghajar, 2011). In a fluid, heat is usually transported by convectional method. Thermal conduction is the major form of heat transport through sedimentary basin (Gupta and Roy, 2007). The magnitude and distribution of geothermal heat flow into the base of the sediments depends on the mechanical and thermal processes of the crust and mantle. The density of a material affects its thermal conductivity. The heat flow in any medium is due to temperature difference between two points within the material (Allen and Allen, 2005).

Two phenomena are responsible for heat flow from the Earth's interior to its surface: earth cooling and radiogenic heat production with a ratio of $17 \%$ to $83 \%$ respectively (Turcotte, 1980). The amount of heat flow into sediment depends on the geothermal conductivity and the thickness of the mantle and crust. Most time, the heat flow into the base of the sediment is used as one of the boundary conditions for heat flow modelling in a sedimentary basin.

Knowledge of subsurface temperature is very important in petroleum hydrocarbons maturation modelling. The only known geothermal research in the Anambra sedimentary basin where this work was carried out is by (Onuoha and Ekine, 1999). They computed the geothermal gradient and heat flow of the basin from measured and corrected bottom hole temperatures of some deep exploratory wells. The bottom hole temperatures were acquired for hydrocarbon exploration by Elf Oil Producing Company, Nigeria.

Oil was first discovered in the Anambra Basin in 1967 at Enugu Otu from Anambra River-1 well drilled by ELF Nigeria Ltd. There was no significant oil accumulation in other wells (Anambra River-2 and 3) drilled near the Anambra River-1 although some gas accumulation was detected. After several years of exploration, the extent and mode of occurrence of the hydrocarbons deposit in the vicinity of Anambra River-1 well has not been established. Due to lack of economic quantity of hydrocarbon in the basin, the company decided to relinquished the concessions thereby terminating the exploration activities. Nevertheless, exploration activities are still on the increase in the basin. The continuous search for hydrocarbon in the basin is due to petroleum geological attributes present in it. Unfortunately, the few wells drilled in the area are limited to depths of only a few kilometres beneath the Earth. This has render complete geothermal characterization of the subsurface that may be related to the presence of hydrocarbon and geothermal systems impossible. For this reason, it is necessary to predict the geothermal properties using alternative ways, one of which is the method of analytical modelling techniques. 
In this research, simple analytical multi-layer solution of 1-D conductive steady state temperature distribution was derived and the result was used to characterized the thermal regime of the subsurface in the study area. The results of the research will be used as an aid for inferring the thermal structure and causes of spatial variation in observed heat flow in the basin. The subsurface temperature modelling is based on assumed basal heat flow and surface temperature. The subsurface temperature was computed for the seven formations in the Anambra sedimentary basin. Information on the geological structure, configuration of rock thermal properties and reliable boundary conditions are very important for geothermal modelling. To test the validity of the model and the assign formation properties the modelled temperatures were compared with measured and corrected bottom hole temperatures from six boreholes. By using different thermal conductivity and thickness values of the seven formations, a reasonable fit for the bottom hole temperatures of the six wells was obtained.

\section{Summary of the Geology of the Study Area}

The Anambra sedimentary basin (Fig. 1) is a late Cretaceous-Palaeocene Proto Niger-Benue Delta Complex. The basin is bounded on the east by the Abakaliki anticlinorium, and on the west by the Precambrian complex rocks of western Nigeria and on the southern part by the upper limits of the Niger Delta Eocene growth faults (Nwajide, 2005: Genik, 1993). The thickness of the basin ranges from $1000-4500 \mathrm{~m}$ (Ladipo et al., 1992). The stratigraphies of the Anambra Basin ranges in age from late Cretaceous to Eocene (Fig. 2). The oldest or basal formation of the Anambra Basin is the CampanoMaastrichtian Agwu shales which is succeeded by the Nkporo Formation. The Nkporo Formations is made up of shales and interbedded sands. The Mamu Formation which overlies the Nkporo Formation ranges in age from Lower to Middle Maastrichtian and the lithologies include shales and sandstones, with some limestones in some parts of the basin. The Mamu Formation is about 100 to $1000 \mathrm{~m}$ thick across the basin. The Mamu Formation is overlain by Ajali Sandstones that has an average thickness of about $300 \mathrm{~m}$. The Nsukka Formation which is the youngest Cretaceous sequence in the basin overlies the Ajali sandstone Formation. The lithology of the Nsukka Formation consists of shales, siltstones, sands and thin coal seams which are interbedded. The Palaeocene Imo shale, Eocene Ameki and the topmost Ogwashi-Asaba Formations, respectively overlie each other conformably after the Nsukka Formation.

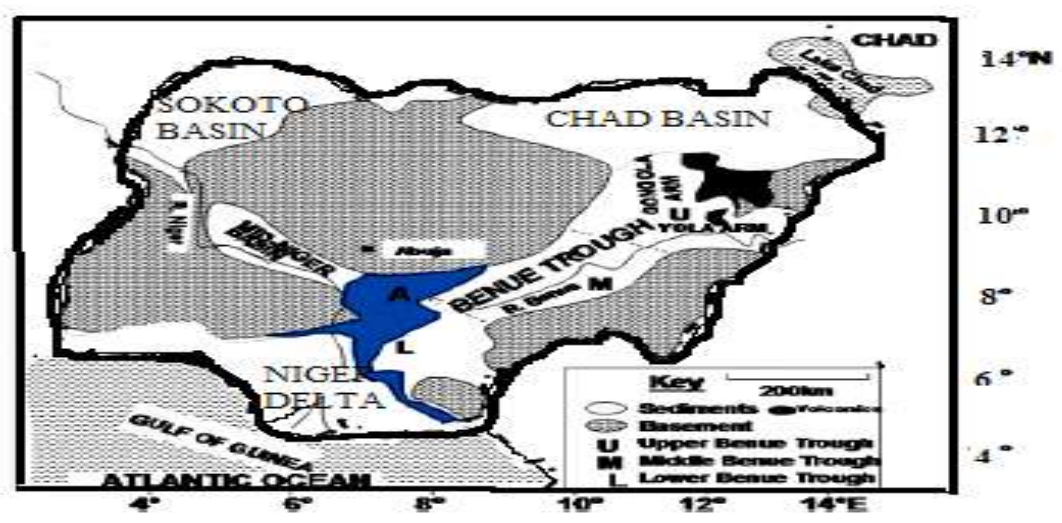

Figure 1: Generalized Geological Map of Nigeria showing the Anambra Sedimentary Basin represented with blue colour (Modified from (Abubakar, 2014)

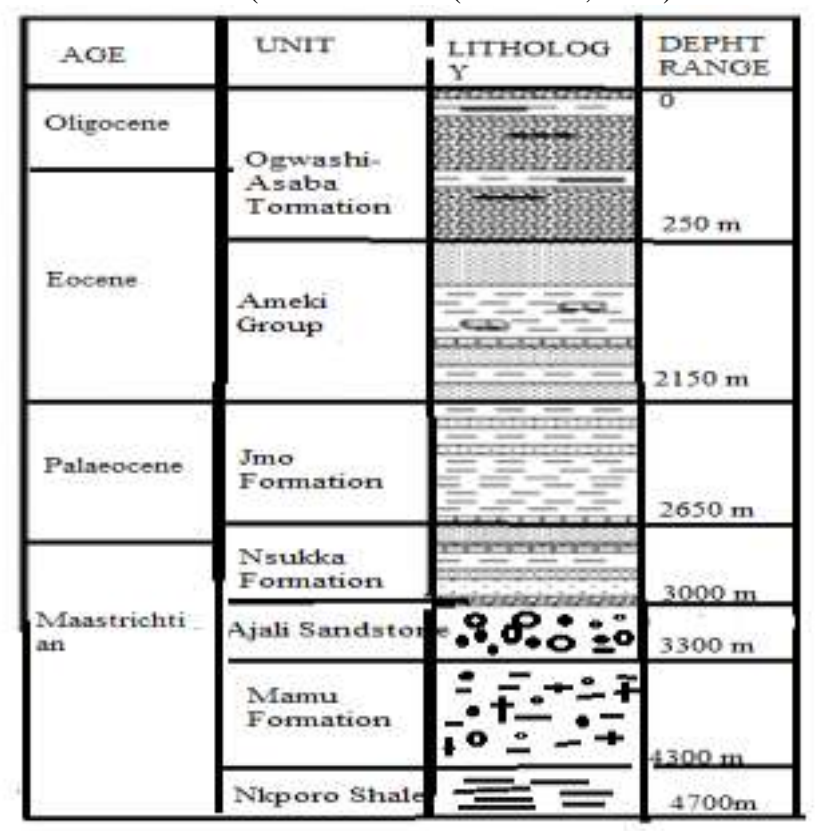

Figure. 2: Summary of the stratigraphic data of the Anambra Basin (From Oboh-Ikuenobe et al., 2005) 
The average thicknesses of the Imo and Ogwashi-Asaba Formations are 500 and 250 metres respectively (Reyment, 1965: Jan du Chẻne et al., 1978: Nwajide, 2005: Arua, 1986: Anyanwu and Arua, 1990). The OgwashiAsaba Formation comprises of alternating coarse-grained sandstone, lignite seams, and light coloured clays of continental origin (Kogbe, 1976). The Anambra basin is smaller than the Niger Delta sedimentary basin and has little growth faults and shale diapers as when compared to the Niger Delta. The main source, reservoir and cap rocks of the basin are the Agwu shales and the Ajali sandstones

\section{Materials and Methods}

Subsurface heat flow and temperature distributions model in sedimentary basins is usually formulated in terms of Fourier's differential equations of heat conduction. The model is normally applied with the assumption that the temperature distribution in the basin is in a steady state and the heat flow boundary condition is independent of the thickness of the basin. The heat flow equation is solved analytically from known surface temperature and the assumed heat flow into the base of the sedimentary basin. The steady state temperature equation in the sedimentary column (Rybach,1985: Lowrie, 2007) is given as

[? $=-$ ? 7 ?

Where

$\mathrm{Q}=$ heat flow

$\mathrm{K}=$ thermal conductivity

$\nabla$ 圆 = geothermal gradient

The minus sign in equation 1 , is due to increase in temperature with depth $(\mathrm{z})$, since heat flows from the subsurface to surface of the earth. This means that heat flows in the negative $\mathrm{z}$ direction (i.e., upwards) while temperature increases in the positive depth direction. The units of the heat flow and thermal conductivity are watts per square metre $\left(\mathrm{Wm}^{-2}\right)$ and watts per metre per degree centigrade $\left(\mathrm{Wm}^{-1} \mathrm{C}^{-1}\right)^{-1}$. For a sedimentary column, equation 1 can also be written as

$$
Q=K_{b} \frac{T_{b}-T_{o}}{H}
$$

Where

$\mathrm{Q}=$ heat flow

$\mathrm{K}_{\mathrm{b}}=$ average bulk thermal conductivity

$\mathrm{T}_{\mathrm{b}}=$ temperature at the base of the column

$\mathrm{T}_{\mathrm{O}}=$ surface temperature

$\mathrm{H}=$ total thickness of the sedimentary column

Making the formation boundary temperature $\left(\mathrm{T}_{\mathrm{b}}\right)$ the subject of formula in equation 2, then

$$
T_{b}=T_{o}+Q \frac{H}{K_{b}}
$$

Assuming that the radioactive heat production in the sedimentary column is negligible, then the heat flow will remain the same in the column. The steady state multilayer solution of equation 3 can be obtained by assuming that the average bulk thermal conductivity of the sedimentary column is equal to the harmonic average of the corresponding single layer thermal conductivities $\mathrm{k}_{\mathrm{i}}$ and the total thickness $\mathrm{H}$ is the summation of the individual thickness hi of the layers that made up the sedimentary column. Applying the principles of thermal harmonic resistance, then

$$
\frac{H}{K_{b}}=\sum_{i}^{n} \frac{h_{i}}{k_{i}}
$$

Substituting equation 4 into equation 3 , we obtained

$$
T_{b}=T_{o}+Q \sum_{i}^{n} \frac{h_{i}}{k_{i}}
$$

Therefore, for the seven Formations in the Anambra basin, equation 5 can be expressed as;

$$
T_{b}=T_{o}+Q\left(\frac{h_{1}}{k_{1}}+\frac{h_{2}}{k_{2}}+\frac{h_{3}}{k_{3}}+\frac{h_{4}}{k_{4}}+\frac{h_{5}}{k_{5}}+\frac{h_{6}}{k_{6}}+\frac{h_{7}}{k_{7}}\right)
$$

The temperatures at the layer boundaries were calculated with equation 6 . The subsurface temperatures were computed for six deep exploratory wells with bottom hole temperatures (Fig. 3) in order to compare the modelled temperatures with the measured temperatures. The temperature was calculated from the surface to the base of the Nkporo Formation. Table 1, shows the initial thermal conductivities and thickness of the individual Formation used for the temperature modelling (Onuoha and Ekine, 1999: Oboh-Ikuenobe et al., 2005). The surface temperature $\left(\mathrm{To}=27^{\circ} \mathrm{C}\right.$ ) and basal heat flow $\mathrm{Q}=50.0$ $\mathrm{mWm}^{-2}$ used for the modelling were also obtained from (Onuoha and Ekine, 1999). Applying the above model parameters in equation 6 , the subsurface temperature distribution in the sedimentary basin was obtained. 


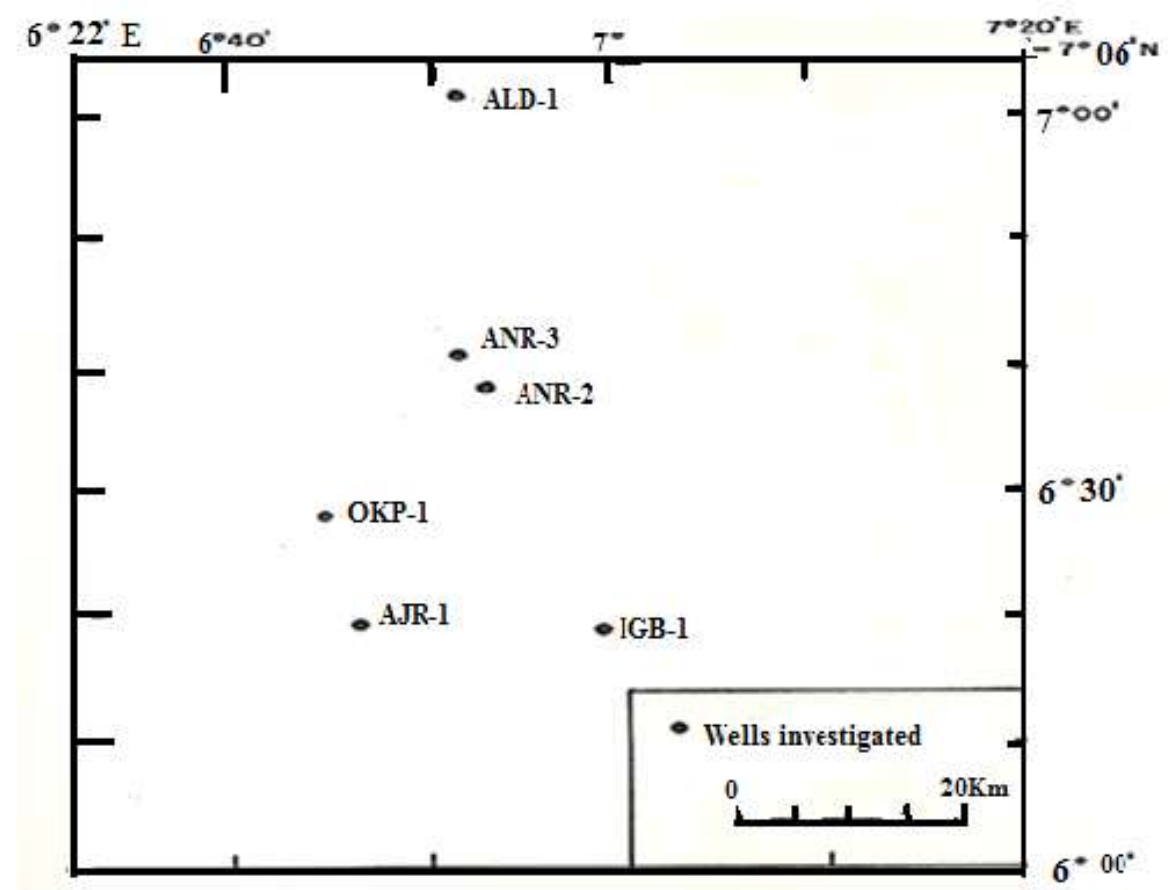

Figure 3: Base Map of the Study Area showing well locations (Modified from (Onuoha and Ekine, 1999)

Table 1: Thermal conductivity and thickness of Formations in Anambra Basin (Onuoha and Ekine, 1999: Oboh-Ikuenobe et al., 2005).

\begin{tabular}{|l|l|l|}
\hline Thermal Conductivity $\left(\mathrm{Wm}^{-1} \mathrm{~K}^{-1}\right)$ & Approximate Thickness Range $(\mathrm{m})$ & Formation \\
\hline 1.4785 & $0-250$ & Ogwashi-Asaba \\
\hline 1.5932 & $250-2150$ & Ameki Group \\
\hline 1.6802 & $2150-2650$ & Imo Shale \\
\hline 1.8267 & $2650-3000$ & Nsukka Formation \\
\hline 2.2183 & $3000-3300$ & Ajali Sandstone \\
\hline 1.941 & $3300-4300$ & Mamu Formation \\
\hline 1.5489 & $4300-4700$ & Nkporo Shale \\
\hline
\end{tabular}

\section{Results and Discussion}

The Anambra basin is made up of about seven (7) Formations and two major lithologies. The Anambra Basin is made up of sequence of sandstones, shales, siltstones, mudstones, sandy shales and coal seams. The temperature and thermal conductivity versus depth profiles generated with equation 6 for the six wells are shown in Figures 4 to 9. The geotherms were generated for boreholes ALD-1, OKP-1, AJR-1, ANR-1, ANR-2 and IGB-1 in the study area. The maximum depth to which the wells were logged ranges between 2200 to 3050 metres.

To test the validity of the model and the assigned formation properties, the model temperatures were compared with measured bottom hole temperatures from the six wells. The measured bottom hole temperatures obtained from Elf Petroleum Nigeria Limited by (Onuoha and Ekine, 1999). They also corrected the raw bottom hole temperatures for drilling effects using the technique of (Leblanc et al., 1981). The results of the comparison between the estimated and corrected measured bottom hole temperatures for the six deep wells in the study area is shown in Table 2. Columns 3 and 4 of the table show the computed and corrected measured temperatures at the various depths. The difference between the estimated and corrected measured temperatures are shown in column 5. The result shows a very good agreement between measured and computed temperature. The difference between them lies between -9 to $8^{\circ} \mathrm{C}$. 

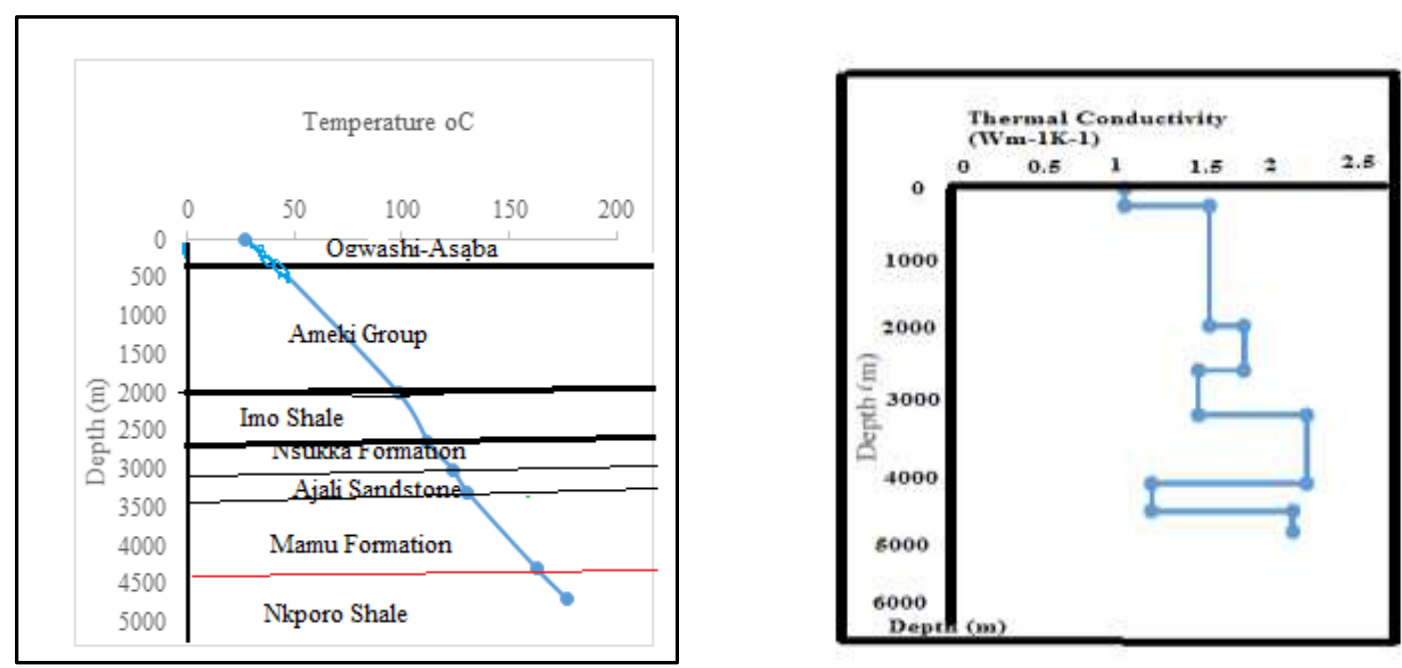

Figure 4: Modelled temperature and thermal conductivity at well Okp-1
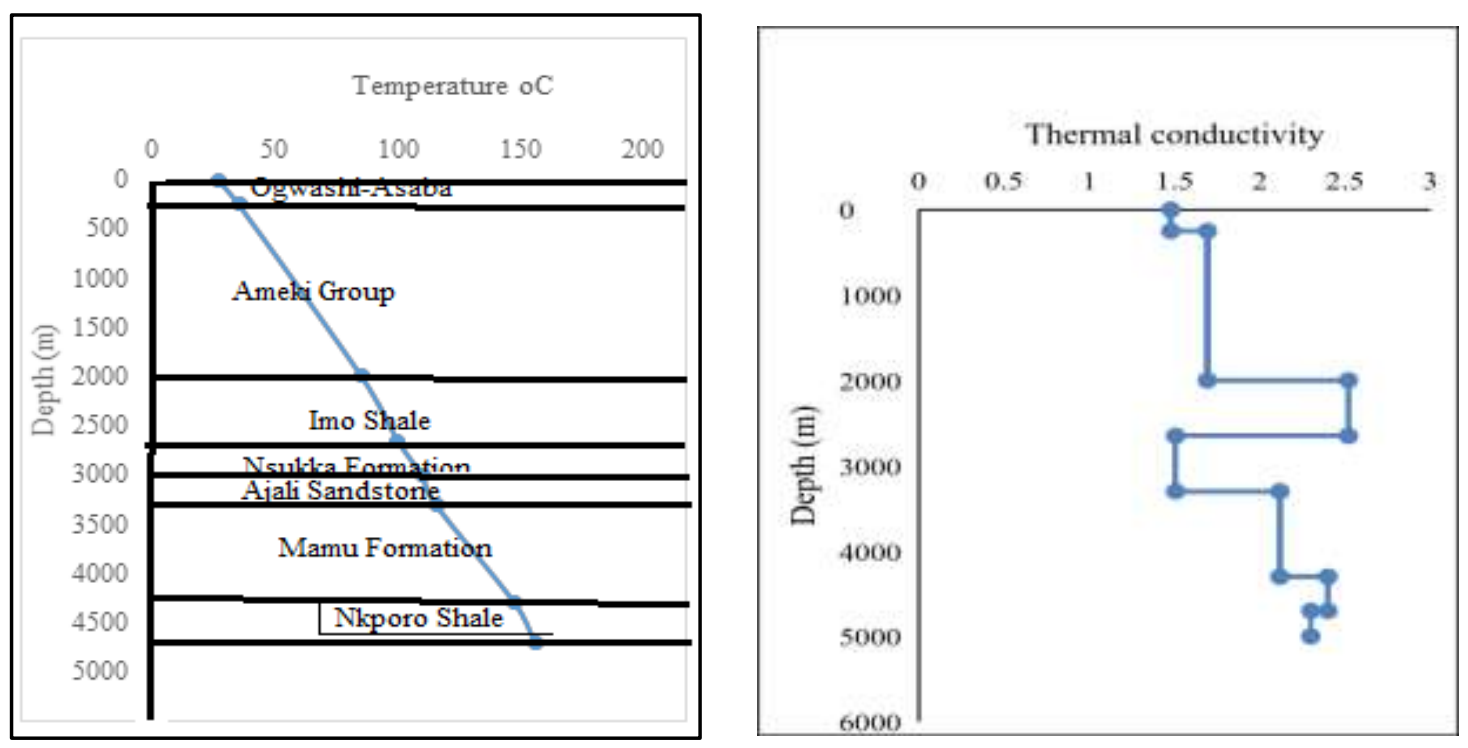

Figure 5: Modelled temperature and thermal conductivity at well ALD-1
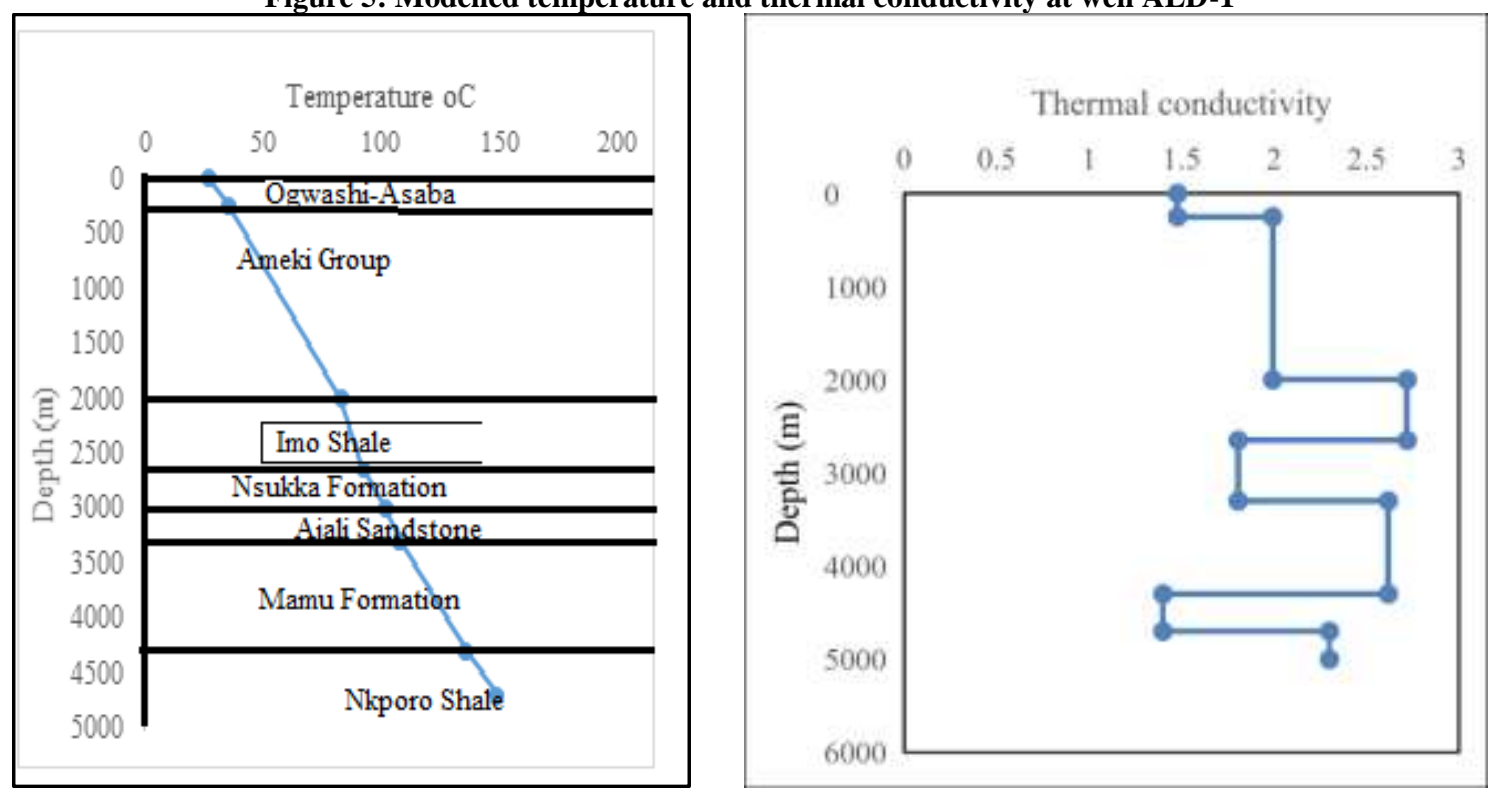

Figure 6: Modelled temperature and thermal conductivity at well AJR-1 

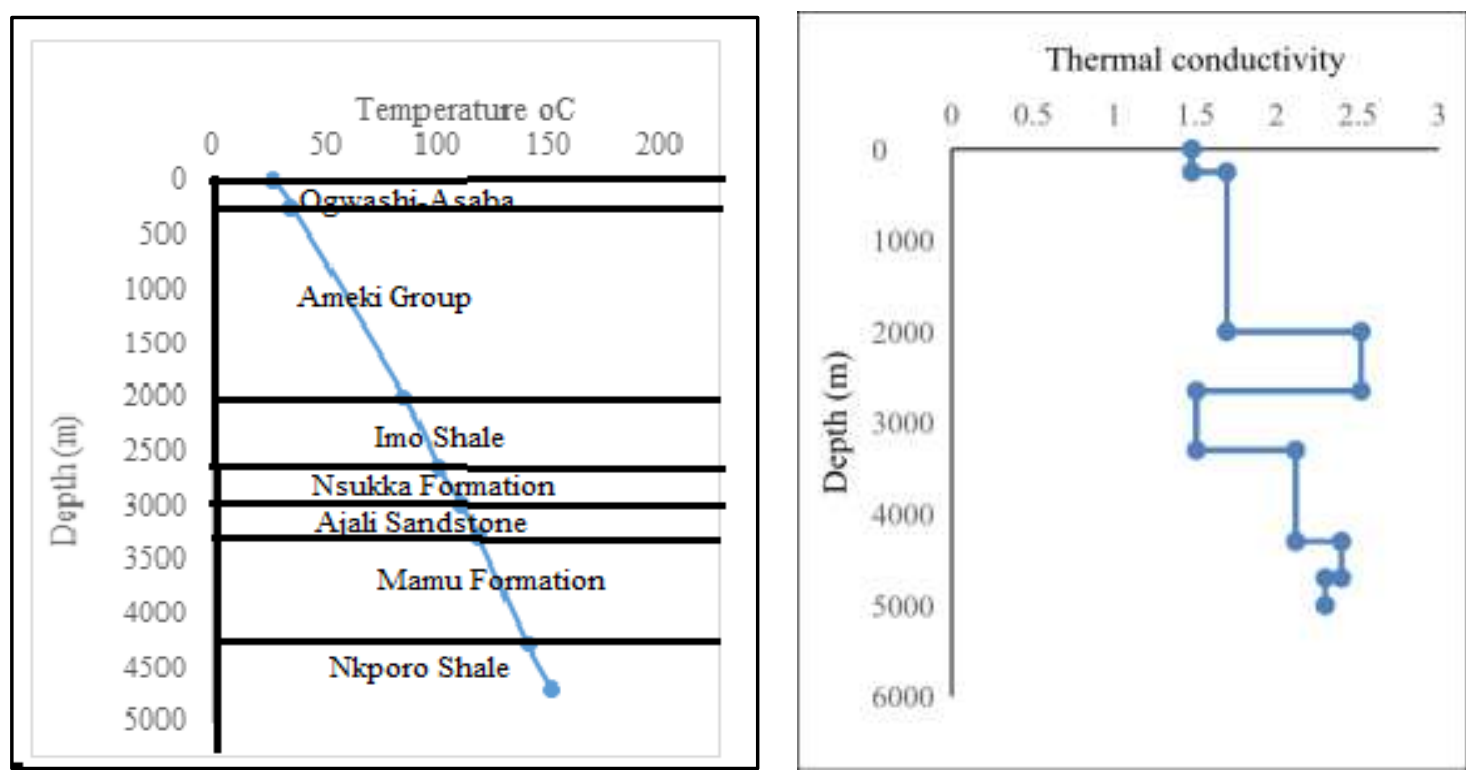

Figure 7: Modelled temperature and thermal conductivity at well IGB-1
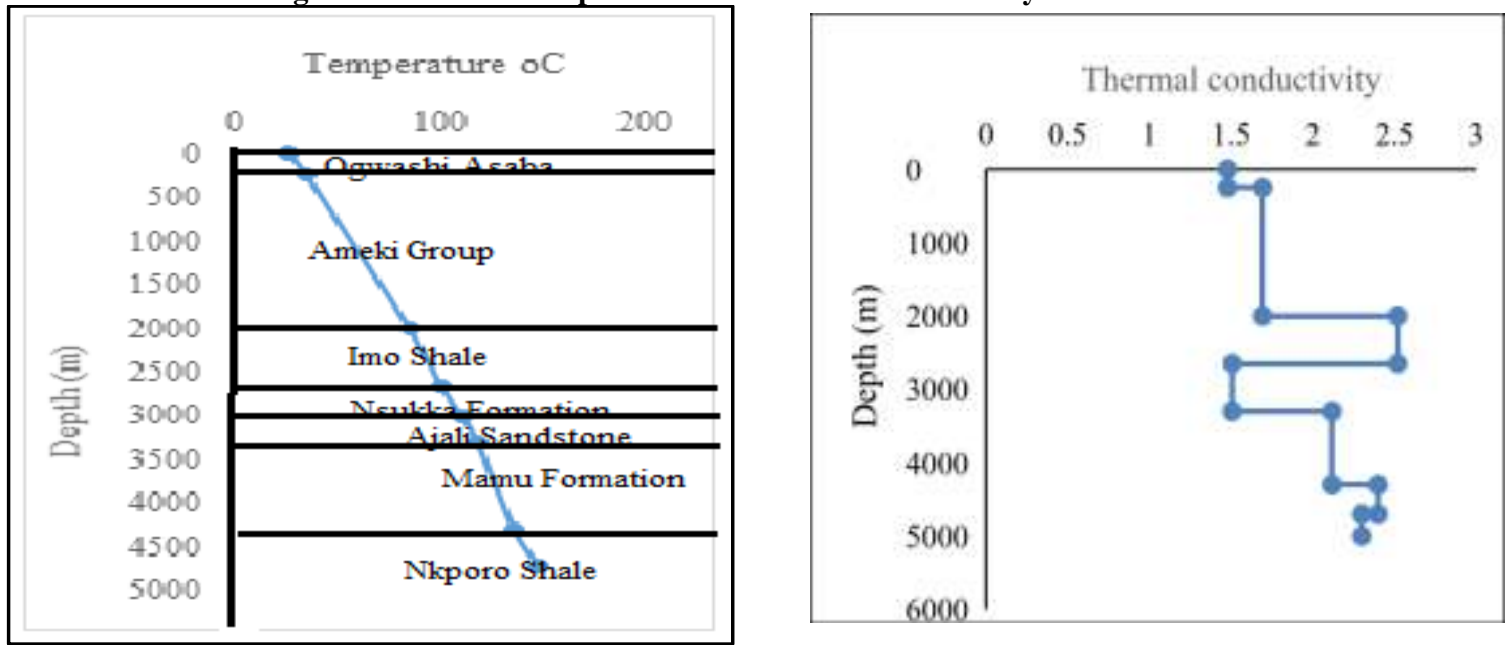

Figure 8: Modelled temperature and thermal conductivity at well ANR-1
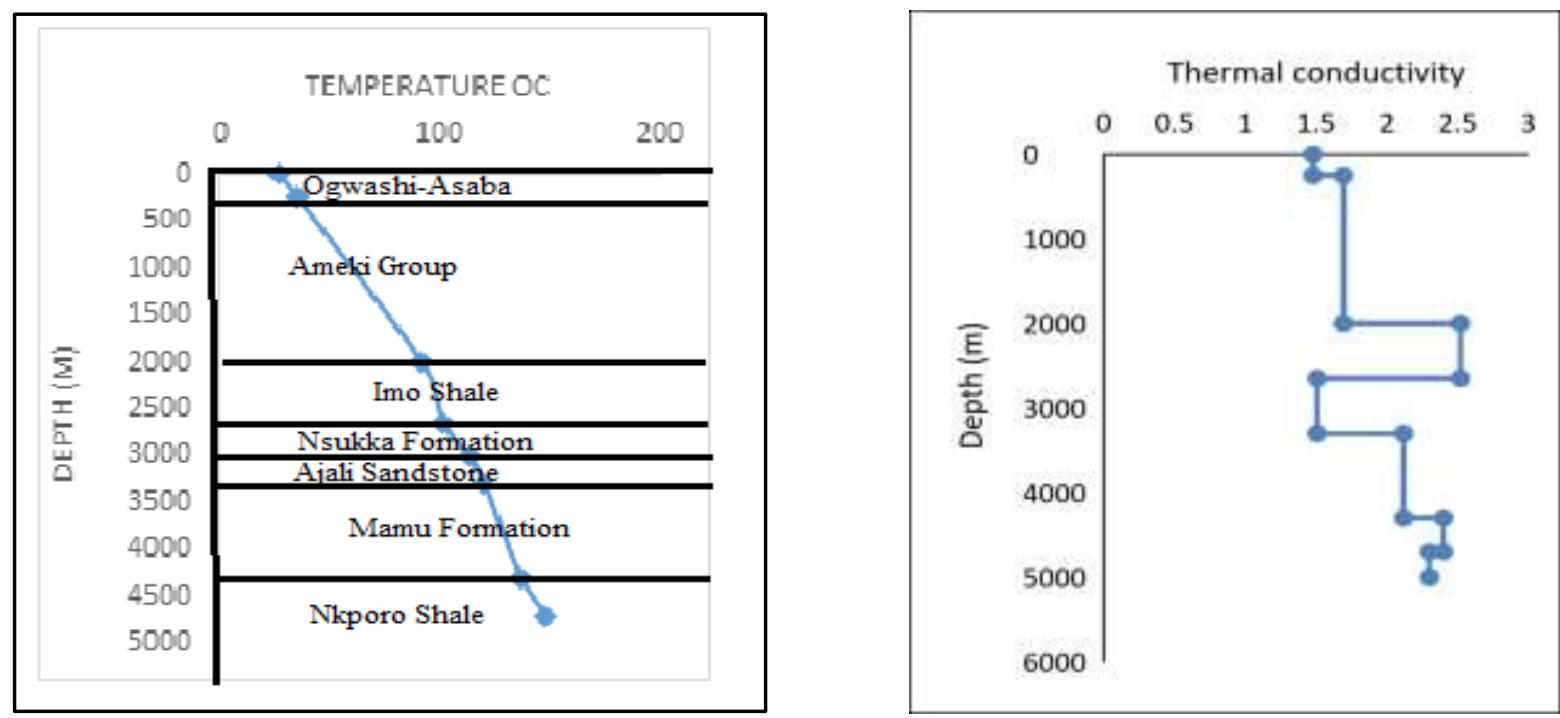

Figure 9: Modelled temperature and thermal conductivity at well ANR-2 
Table 2: Comparison of computed and measured temperature at some depths in the six borehole

\begin{tabular}{|c|c|c|c|c|}
\hline $\begin{array}{l}\text { Difference between estimated } \\
\text { and measured Temperature }\end{array}$ & $\begin{array}{l}\text { Measured bottom hole } \\
\text { temperature }\left({ }^{\circ} \mathrm{C}\right)\end{array}$ & $\begin{array}{l}\text { Estimated } \begin{array}{ll}\text { bottom } & \text { hole } \\
\text { temperature }\left({ }^{\mathrm{o}} \mathrm{C}\right)\end{array}\end{array}$ & Depth (Metres) & Well \\
\hline 1.083 & 27 & 28.083 & 0 & \\
\hline-2.557 & 69 & 66.443 & 1400 & ALD-1 \\
\hline-8.897 & 100 & 91.103 & 2300 & \\
\hline 6.653 & 108 & 111.653 & 3050 & \\
\hline 3.078 & 27 & 30.078 & 0 & \\
\hline-9.492 & 80 & 70.508 & 1300 & OKP-1 \\
\hline-9.942 & 96 & 86.056 & 1800 & \\
\hline 1.608 & 100 & 101.608 & 2300 & \\
\hline 3.828 & 104 & 107.828 & 2500 & \\
\hline 1.039 & 27 & 28.039 & 0 & AJR-1 \\
\hline-4.241 & 60 & 55.759 & 1100 & \\
\hline 8.439 & 70 & 78.439 & 2000 & \\
\hline-5.961 & 97 & 91.039 & 2500 & \\
\hline 3.9469 & 27 & 30.9469 & 0 & ANR-3 \\
\hline 5.6469 & 64 & 69.6469 & 1500 & \\
\hline 0.3869 & 77 & 77.3869 & 1800 & \\
\hline 2.1889 & 93 & 95.1889 & 2490 & \\
\hline 4.841 & 27 & 31.841 & 0 & \\
\hline 5.821 & 62 & 67.821 & 1400 & ANR-2 \\
\hline 8.101 & 70 & 78.101 & 1800 & \\
\hline 0.381 & 88 & 88.381 & 2200 & \\
\hline 2.711 & 27 & 29.711 & 0 & IGB-1 \\
\hline 0.641 & 58 & 58.641 & 1100 & \\
\hline-1.539 & 97 & 95.461 & 2500 & \\
\hline 2.036 & 100 & 102.036 & 2750 & \\
\hline
\end{tabular}

The temperature-depth profiles show that the estimated temperatures increase with depth within the sedimentary basin. The temperature versus depth curves show zones of steep and low increases in temperature with depth. These zones of steep and low gradient correspond to low and high values of thermal conductivities. The zones of steep gradient within a geotherm is due to low thermal conductivity. The steepness of the profile (high values of the geothermal gradient) at depth may be as a result of overpressure due to under compaction and presence of shale having lower thermal conductivity. The estimated thermal conductivities profiles show variation with depth. The thermal conductivity seems to increase with depth. The increase in thermal conductivity with depth may be due to increases in compaction of the sediments with depth. The Imo shale and Ajali (3rd and 5th) formations have the dominant thermal conductivity in all the wells while the OgwashiAsaba formation has the least. A change in thermal conductivity and temperature are well pronounced at most of the boundaries. The accuracy of the temperature model depends on the quality of input data such as thermal conductivities, basal heat flow, geological structures and thickness of the layers. For the present study, corrected measured bottom-holetemperature values were used for the model calibration. The results of the comparison between the estimated and measured bottom hole temperature for the six deep wells in the study area shows a very good agreement between measured and computed temperatures. The difference between them lies between -9 to $8^{\circ} \mathrm{C}$. Knowledge of the geological structure, the configuration of the rock thermal properties and boundary conditions are important for the setup of thermal models. The interaction of geological structure, thickness distribution and rock thermal properties is crucial for the modelling of the subsurface thermal field.

\section{Conclusion}

In this paper the subsurface temperature and thermal conductivity of the formations of Anambra sedimentary basin have been model from multilayer solution of heat flow equation by using thermal resistance techniques. The computed geotherm for the six exploratory wells show that the temperature increases with the depth within the basin. Comparison of the computed geotherms with measured bottom hole temperatures for the six deep wells shows good agreement. It was observed that the modelled temperatures and thermal conductivities vary vertically and spatially. This may be attributed to the complex geological structures in the subsurface, the thickness of the sediment, regional and local geological variability and associated differences in lithology. This state of the art techniques is simple and only require basal heat flow, thickness of formations, surface temperature and bulk thermal conductivities of formations as input data.

\section{References}

[1.] Abubakar, N. B. (2014) .Petroleum potential of the Nigerian Benue trough and Anambra basin: A regional synthesis. Natural Resources, 5: 25-58

[2.] Allen, P. A., Allen, J. R. (2005).Basin Analysis. Blackwell Publishing, second Edition.

[3.] Anyanwu, N. P. C., Arua, I.. (1990). Ichnofossils from the Imo Formation and their palaeoenvironmental significance. Journal of mining and Geology 26, 1-4

[4.] Arua, I. (1986). Paleoenvironment of Eocene deposits in the Afikpo syncline, southern Nigeria. Journal of African Earth Sciences 5, $279-284$.

[5.] Beardsmore, G. R., Cull, J. P. (2001). Crustal Heat Flow. Cambridge University Press

[6.] Cengel, Y., Ghajar, A. J. (2011). Heat and Mass Transfer: Fundamentals and Applications $4^{\text {th }}$ Edition in SI Units. New York, NY: McGraw-Hill Higher Education.

[7.] Chapman, D. S. Keho, T. H., Baure, M. S., Picard, M. D. (1984). Heat flow in Uinta Basin determined from bottom hole temperature data. 
Geophysics 49, 453-466.

[8.] Chapman, D. S., Rybach, L. (1985). Heat flow anomalies and their interpretation, in Heat flow and Geothermal processes, ed. Rybach. L., Journal of Geodyn. 4,3-37.

[9.] Genik, G. J. Petroleum geology of Cretaceous-Tertiary rift basins in Niger, Chad and Central African Republics, AAPG Bulletin, 77(8), (1993): $1405-1434$.

[10.] Goff, F., Janik, C. J. (2000). "Geothermal systems," in Encyclopedia of Volcanoes, H.Sigurdsson, (Ed). Academic Press, 817-835.

[11.] Gupta, H. K., Roy, S. (2007).Geothermal Energy: An Alternative Resource for the 21st Century. Amsterdam: Elsevier

[12.] Jan du Chėne, R., Onyike, M. S., Sowumi, M. A. (1978). Some new Eocene pollen of ogwashi-Asaba Formation, southeastern Nigeria. Revista de Espanol micropaleontology 10, 285-322.

[13.] Kogbe, C. A. 1976). Palaeogeographic history of Nigeria from Albian Times, In: C.A. Kogbe, ED., Geology of Nigeria, Elisabethan publishing Co, Lagos, (237-252.

[14.] Ladipo, K. O., C. S. Nwajide, Akande, S. O. (1992). Cretaceous and Paleogene sequences in the Abakaliki and Anambra basins, southern Nigeria. A field guide, 'International symposium on the geology of Deltas, Port Harcourt, p.39.

[15.] Leblanc, Y., Pascoe, L. J., Jones, F. W. (1981). The temperature stabilisation of a borehole. Geophysics, 45, 1302-1303

[16.] Lowrie, W. (2007). Fundamentals of Geophysics. Cambridge: Cambridge University Press. 2nd, edition

[17.] Nwajide, C. S. (2005). Anambra basin of Nigeria: Synoptic basin analysis as a basis for evaluating its hydrocarbon prospectivity, 'In C. O. Okogbue, Ed., Hydrocarbon potentials of the Anambra basin: Geology, geochemistry and geohistory perspectives, Great AP express publisher limited, Nsukka, 83-110

[18.] Oboh-Ikuenobe, F. E., Obi, C. G., Jaramillo, C. A. (2005). Lithofacies, palynofacies, and sequence stratigraphy of Paleogene strata in Southeastern Nigeria. Journal of African Earth Sciences 41, 79-102.

[19.] Onuoha, K. M., Ekine, A. S. (1999). Subsurface temperature variations and heat flow in the Anambra Basin, Nigeria. Journal of African Earth Science 28(3), 641-653.

[20.] Putra, S, D, H., Fajar, S. J., Srigutomo, W. (2014). Numerical modelling of 2D conductive heat transfer and its application for the characterization of geothermal systems. International Conference on Physics, Atlantis, 51-61.

[21.] Reyment, R. A. (1965). Aspects of the Geology of Nigeria, Ibadan University press, Ibadan.

[22.] Safanda, J. (1985). Calculation of temperature distribution in two-dimensional geothermal profile,” Studia geoph. et geod. 29, 197-207.

[23.] Stuwe, K. (2008). Principles of heat flow modelling. Course notes on heat flow for Intrepid Geophysics

[24.] Turcotte, D. L. (1980). On the thermal evolution of the earth. Earth and Planetary Science Letters 48, 53-58.

[25.] Whiteford, P. C., Graham, D. J. (1994). Conductive heat flows through the sediments in Lake Rotomahana, New Zealand. Geothermics 23, 527-538. 